\title{
Identify biosorption effects of Thiobacillus towards perfluorooctanoic acid (PFOA): Pilot study from field to laboratory
}

\author{
Lei Li ${ }^{\text {a, b }}$, Tieyu Wang a, b, *, Yajun Sun ${ }^{\text {c }}$, Pei Wang ${ }^{\text {a, b }}$, Baninla Yvette ${ }^{\text {a, b }}$, Jing Meng ${ }^{\text {a, b }}$, \\ Qifeng Li ${ }^{\text {a, b }}$, Yunqiao Zhou ${ }^{\text {a, b }}$ \\ a State Key Laboratory of Urban and Regional Ecology, Research Center for Eco-Environmental Sciences, Chinese Academy of Sciences, Beijing 100085, China \\ ${ }^{\mathrm{b}}$ University of Chinese Academy of Sciences, Beijing 100049, China

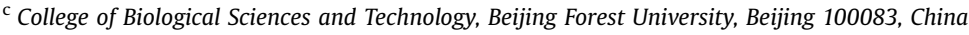

\section{H I G H L I G H T S}

- PFOA was the predominant PFAAs in all sediment samples from Xiaoqing River.

- High level PFOA could induce evident increase of Thiobacillus abundance in sediment.

- T. thioparus could be growing and thriving in medium with high PFOA concentration.

- T. thioparus could be applied as a potential biosorbent to eliminate PFOA in water.

\section{A R T I C L E I N F O}

\section{Article history:}

Received 7 October 2016

Received in revised form

7 December 2016

Accepted 9 December 2016

Available online 13 December 2016

Handling Editor: Shane Snyder

\section{Keywords:}

PFOA

Thiobacillus thioparus

Thiobacillus denitrificans

Biosorption

Ecological remediation

\section{G R A P H I C A L A B S T R A C T}

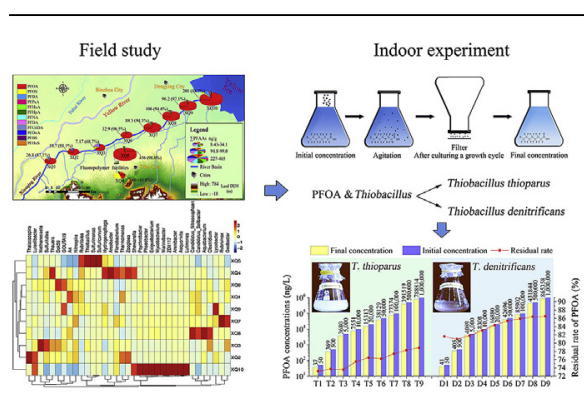

\begin{abstract}
A B S T R A C T
The concentration of Perfluoroalkyl acids (PFAAs) and the bacterial community composition along the Xiaoqing River were explored with HPLC-MS/MS and Illumina high-throughput sequencing in present study. The results showed that perfluorooctanoic acid (PFOA) was the predominant PFAAs in all sediment samples, and high level of PFOA could lead to an evident increase in the abundance of Thiobacillus. Thiobacillus was identified with the survival ability in high concentrations of PFOA accordingly. Therefore, Thiobacillus thioparus and Thiobacillus denitrificans were selected as receptors to design indoor biosorption experiment. The growth curves under different PFOA concentrations and residual rates of PFOA in the processes of cultivation were analyzed. The results showed that upwards concentrations of PFOA below $5000 \mathrm{ng} / \mathrm{L}$ led to an obvious increase in the growth rate of $T$. thioparus. Whereas PFOA promoted the growth of $T$. denitrificans in a relatively limited range of concentration, and the effect was not obvious. The addition of different concentrations of PFOA had no apparent effects on pH values in the media of both T. thioparus and T. denitrificans. The concentrations of PFOA in liquid media reduced after the process of bacteria culturing. The removal rates of T. thioparus and T. denitrificans to PFOA were $21.1-26.8 \%$ and $13.5-18.4 \%$, respectively. The current findings indicated that $T$. thioparus could play a significant role as potential biosorbent with the ability to eliminate PFOA effectively in aquatic environment, which would provide novel information for PFOA ecological decontamination and remediation.
\end{abstract}

(c) 2016 Elsevier Ltd. All rights reserved.

\footnotetext{
* Corresponding author. State Key Laboratory of Urban and Regional Ecology, Research Center for Eco-Environmental Sciences, Chinese Academy of Sciences, Beijing 100085, China.

E-mail address: wangty@rcees.ac.cn (T. Wang).
} 


\section{Introduction}

Perfluoroalkyl acids (PFAAs) are emerging halogenated hydrocarbons used in various consumer and industrial products such as surfactants, foam extinguishers, fabrics and food packaging (Giesy and Kannan, 2002; Yeung et al., 2009). These perfluorinated compounds are characterized by strongly reducing surface tension, extraordinary thermal and chemical stability (Kissa, 2001). Moreover, on account of the strength of the carbon-fluorine bond, they are environmentally persistent with resistance to hydrolysis, photolysis, biological metabolism, and are not subject to microbial degradation (Giesy and Kannan, 2001). Within the PFAAs group, perfluorooctanoic acid (PFOA) is highly water-soluble and easily transferred in aquatic environment. PFOA has become a worldwide contaminant, detected in sediments (Zhu et al., 2014), municipal wastewater (Ma and Shih, 2010), sludge (Yu et al., 2009), tap water (Mak et al., 2009), etc.

The widespread of PFOA has caused environmental and public health issues, thus raising ecological and toxicological concern about its potential risk to organisms (Rayne and Forest, 2009). The different toxic effects of PFOA towards human and animals have been studied, such as reproductive dysfunction, developmental toxicity, carcinogenicity, mutagenicity and immunotoxicity (Giesy and Kannan, 2001; Lau et al., 2007; Olsen et al., 2009; Persson et al., 2013). In view of that, the decontamination of PFOA has been widely debated as well. Several categories of PFOA abatement methods have been developed over the past decades including photoelectrocatalysis (Li et al., 2016), photolytic (Yamamoto et al., 2007), zerovalent iron reduction (Hori et al., 2006), sonolysis (Yamamoto et al., 2007) and other techniques (Krusic et al., 2005; Ochoa-Herrera et al., 2008). However, the harsh treatment conditions and high energy consumption are required, which result in the limited scope of application, underscoring the need for further research of alternative approaches to decontaminate PFOA.

Biosorption is a number of metabolism-independent processes (Vijayaraghavan and Yun, 2008), which has attracted a great deal of attention. The properties of certain types of microbial biomass make it possible to detoxify pollutants from industrial effluents and other aqueous solutions with low cost, easy availability and moderate operating conditions (Aksu, 2005; Dobson and Burgess, 2007; Fomina and Gadd, 2014). A variety of studies have focused on some microorganisms including bacteria (Aksu, 2005; Kwak et al., 2013), fungi (Mezaguer et al., 2013; Aytar et al., 2014) and yeast (Soares and Soares, 2012; Imandi et al., 2014), which are capable of absorbing pollutants from wastewater. However, the literature survey indicated that the studies relating to biosorption are very limited and only the purification of selected pollutants have been studied such as metals (Aytar et al., 2014; Hlihor et al., 2015) and dyes (Deniz and Ersanli, 2016; Deniz and Kepekci, 2016). There is a need to study other pollutants, especially PFOA which are not easily biodegradable, and to identify the specific species which can provide abundant biomass with simple growth conditions, inexpensive media and high biosorption capacity.

The bacterial species with stronger adaptability and tolerance to PFOA might have a higher relative abundance in the environment media polluted by PFOA. However, there are various types of chemicals in environment involving heavy metals, petroleum hydrocarbons, polynuclear aromatic hydrocarbons, pesticides, etc. As a result, it is necessary to conduct further laboratory experiments to exclude other factors which could interfere the result, as well as to demonstrate the survivability and absorbability of certain bacteria more persuasively. Therefore, in the present study, we explored a new perspective of research that extended field study to indoor experiment to get comprehensive information about bacteria species which have the potential ability to absorb PFOA. We selected the Xiaoqing River in Shandong Province of China as study area which is relatively urbanized and industrialized with fluorochemical industry, and high PFOA loads were quantified by Wang et al. (2016). In field investigation stage, the bacterial community compositions were explored with Illumina high-throughput platform to identify the most abundant bacteria genera in the field with PFOA pollution. In laboratory simulation, the sorption behaviors of identified bacteria species towards PFOA were analyzed by measuring growth curves under different PFOA concentrations and the reduction effects. The results will provide novel information for PFOA ecological remediation and pollution mitigation, especially for the PFOA contaminated watersheds.

\section{Materials and methods}

\subsection{Sample collection}

10 surface sediment samples (XQ1-XQ10) were collected along the Xiaoqing River in Shandong Province of China in April 2014 (Fig. S1), where various PFAAs manufacturers were located. In particular, a previous study found that the fluoropolymer facilities at the upstream of site XQ5 caused more pollution than other sources (Wang et al., 2016). Xiaoqing River originates in Jinan City, and runs through Zibo City, Binzhou City, Dongying City and Weifang City before emptying into the Laizhou Bay, which is one of the three major bays in the Bohai Sea. The length of Xiaoqing River is $237 \mathrm{~km}$ and the watershed area is $11,000 \mathrm{~km}^{2}$. Surface sediment samples $(0-15 \mathrm{~cm})$ were collected from four corners in each site with the area of $2 \mathrm{~m} \times 2 \mathrm{~m}$ by a sediment sampler (Peterson dredge, China), and then harvested into $500 \mathrm{~mL}$ sterile polypropylene (PP) bottles and mixed to produce one composite sample for each site. All sediment samples were stored in ice boxes and transferred to the laboratory immediately. One part was grinded after freezedrying to pass a $2 \mathrm{~mm}$ mesh sieve for further analysis, and the other part was kept at $-80{ }^{\circ} \mathrm{C}$ before DNA extraction.

\subsection{PFAAs extraction and analysis}

Sediment samples were extracted mainly using a previously published method with minor optimizations and modifications described by Naile et al. (2010). A total of 12 linear PFAAs including 9 PFCAs with carbon lengths from C4 to C12 and 3 perfluoroalkane sulfonic acids (PFSAs) were measured in this study. In detail, perfluoro-butanoic acid (PFBA), perfluoro-pentanoic acid (PFPeA), perfluoro-hexanoic acid PFCAs (PFHxA), perfluoro-heptanoic acid (PFHpA), perfluoro-octanoic acid (PFOA), perfluoro-nonanoic acid (PFNA), perfluoro-decanoic acid (PFDA), perfluoro-undecanoic acid (PFUnDA), perfluoro-dodecanoic acid (PFDoA), perfluoro-butane sulfonate (PFBS), perfluoro-hexane sulfonate (PFHxS), perfluorooctane sulfonate (PFOS) were quantified. The instrumental analysis was performed using Agilent 1290 high performance liquid chromatography system equipped with an Agilent 6460 triplequadrupole mass spectrometer (Agilent Technologies, Palo Alto, CA), which was operated in a negative electrospray ionization (ESI) mode. The details of HPLC and ESI-MS instrument conditions were available in Supporting Information and Table S1.

\subsection{DNA extraction, amplification and sequencing}

DNA was extracted from surface sediment samples using the FastDNA ${ }^{\text {TM }}$ SPIN Kit for Soil (MP Biomedicals, USA) according to the specification. The extracted DNA was determined by $1.5 \%$ agarose gel electrophoresis, which was stored at $-20^{\circ} \mathrm{C}$ for further analysis.

Taxonomic profiling of the microbial community was performed using Illumina ${ }^{\circledR}$ MiSeq sequencing combinatorial sequence-tagged 
PCR products. In order to amplify bacteria specific V4 hyper variable region of the $16 \mathrm{~S}$ rRNA gene, the 806R (5'-GGACTACHVGGGTWTCTAAT- $3^{\prime}$ ) and 515F (5'-GTGCCAGCMGCCGCGGTAA-3') primers were used (Bates et al., 2011). PCR amplification was conducted in a $30 \mu \mathrm{L}$ reaction system containing $0.2 \mu \mathrm{M}$ forward and reverse primers, $15 \mu \mathrm{L}$ Phusion ${ }^{\circledR}$ High-Fidelity PCR Master Mix with GC buffer (New England Biolabs, USA) and $10 \mu \mathrm{L}$ template DNA. PCR amplification program contains 1 min initial denaturation at $98^{\circ} \mathrm{C}, 30$ cycles of amplification ( $10 \mathrm{~s}$ denaturation at $98^{\circ} \mathrm{C}$, $30 \mathrm{~s}$ annealing at $50^{\circ} \mathrm{C}, 60 \mathrm{~s}$ extension at $72{ }^{\circ} \mathrm{C}$ ) and a $5 \mathrm{~min}$ final elongation at $72{ }^{\circ} \mathrm{C}$. The PCR products were purified with Gene JET Gel Extraction Kit (Thermo Scientific). The DNA genes from sediment samples were sequenced by Illumina MiSeq platform after the DNA library was constructed. Paired-end reads were jointed with Flash (Magoč and Salzberg, 2011), and the chimeras detected by UCHIME and low quality sequences were removed (http://qiime. org/scripts/split_libraries_fastq.html).

\subsection{Microbe classification}

The resulting high quality sequences were clustered into operational taxonomic units (OTUs), which were defined at the $97 \%$ similarity threshold with the UPARSE program (Edgar, 2013) in the QIIME software package (V1.6.0, http://qiime.org/index.html). The taxonomic classification of OTU-representative reads to the genus level was conducted with the Ribosomal Database Project (RDP) Bayesian classifier with minimum confidence of $80 \%$.

\subsection{Microbial indoor experiment}

\subsubsection{Strain and media formulations}

Thiobacillus thioparus and Thiobacillus denitrificans were purchased from the Japan Collection of Microorganisms (JCM).

The medium of $T$. thioparus was composed of $1.5 \mathrm{~g} \mathrm{KH}_{2} \mathrm{PO}_{4}, 4.5 \mathrm{~g}$ $\mathrm{Na}_{2} \mathrm{HPO}_{4}, 0.3 \mathrm{~g} \mathrm{NH}_{4} \mathrm{Cl}, 0.1 \mathrm{~g} \mathrm{MgSO}_{4} \cdot 7 \mathrm{H}_{2} \mathrm{O}, 100.0 \mathrm{~mL}$ of $10 \% \mathrm{Na}_{2} \mathrm{~S}_{2} \mathrm{O}_{3}$ solution and $5.0 \mathrm{~mL}$ of a trace metal solution in $900.0 \mathrm{~mL}$ of distilled water. The final $\mathrm{pH}$ was 7.5 and $\mathrm{Na}_{2} \mathrm{~S}_{2} \mathrm{O}_{3}$ solution was sterilized by filtration separately. Aseptically add sterile $\mathrm{Na}_{2} \mathrm{~S}_{2} \mathrm{O}_{3}$ solution to the medium. The trace metal solution was composed of $50.0 \mathrm{~g}$ EDTA, $22.0 \mathrm{~g} \mathrm{ZnSO}_{4} \cdot 7 \mathrm{H}_{2} \mathrm{O}, 5.06 \mathrm{~g} \mathrm{MnCl}_{2} \cdot 4 \mathrm{H}_{2} \mathrm{O}, 4.99 \mathrm{~g} \mathrm{FeSO}_{4} \cdot 7 \mathrm{H}_{2} \mathrm{O}, 5.54 \mathrm{~g}$

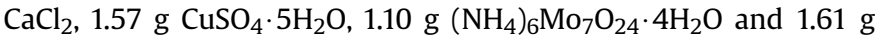
$\mathrm{CoCl}_{2} \cdot 6 \mathrm{H}_{2} \mathrm{O}$ in $1.0 \mathrm{~L}$ of distilled water. The $\mathrm{pH}$ was adjusted to 6.0 with $\mathrm{KOH}$.

The medium of $T$. denitrificans was made up of $5.0 \mathrm{~g} \mathrm{KNO}_{3}, 0.5 \mathrm{~g}$

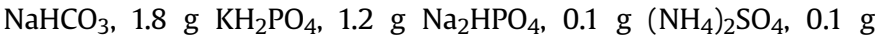
$\mathrm{MgSO}_{4} \cdot 7 \mathrm{H}_{2} \mathrm{O}, 30.0 \mathrm{mg} \mathrm{FeCl} \cdot 6 \mathrm{H}_{2} \mathrm{O}, 30.0 \mathrm{mg} \mathrm{MnSO}{ }_{4} \cdot \mathrm{xH}_{2} \mathrm{O}, 40.0 \mathrm{mg}$ $\mathrm{CaCl}_{2} \cdot 2 \mathrm{H}_{2} \mathrm{O}$ and $100.0 \mathrm{~mL}$ of $10 \% \mathrm{Na}_{2} \mathrm{~S}_{2} \mathrm{O}_{3}$ solution in $900 \mathrm{~mL}$ of distilled water. The final pH was 7.0. Separately sterilize $\mathrm{Na}_{2} \mathrm{~S}_{2} \mathrm{O}_{3}$ solution by filtration. Aseptically add sterile $\mathrm{Na}_{2} \mathrm{~S}_{2} \mathrm{O}_{3}$ solution to the medium as above.

\subsubsection{Experimental design}

This experiments at ten grades of PFOA concentrations $(0,50$, $\left.500,5000,10^{4}, 2 \times 10^{4}, 5 \times 10^{4}, 10^{5}, 5 \times 10^{5}, 10^{6} \mathrm{ng} / \mathrm{L}\right)$ were designed to detect growth curves, $\mathrm{pH}$, as well as the final PFOA concentrations of the two species. The liquid media were dispensed into flasks. Addition of the bacterial suspension of T. thioparus and T. denitrificans were $10 \%$ of pre-cultured inoculum. T. thioparus was cultured aerobically in an incubator Shaker (HYG-A, Beijing, China) at $30{ }^{\circ} \mathrm{C}$ for $108 \mathrm{~h}(4.5 \mathrm{~d})$, and T. denitrificans was cultured anaerobically in a biochemical incubator (LRH-250A, Tianjin, China) at $30{ }^{\circ} \mathrm{C}$ for $12 \mathrm{~d}$. The $T$. thioparus growth curve was determined by turbidimetry using an Infinite ${ }^{\circledR} 200$ Pro NanoQuant at the wavelength of $600 \mathrm{~nm}$. The OD values and the $\mathrm{pH}$ at the initial time, $12 \mathrm{~h}$, 24 h, 36 h, 48 h, 60 h, 72 h, 84 h, 96 h, 108 h of growth were measured. The T. denitrificans growth curve was determined at the wavelength of $420 \mathrm{~nm}$. The OD values and $\mathrm{pH}$ at the initial time and each $24 \mathrm{~h}$ for $12 \mathrm{~d}$ of culturing were measured.

Next the liquid media of T. thioparus and T. denitrificans under ten different PFOA concentrations after inoculating $108 \mathrm{~h}$ and $12 \mathrm{~d}$ were collected into a $50 \mathrm{~mL}$ PP centrifuge tube. Firstly, the media and bacteria were separated by centrifugation at $2000 \mathrm{rpm}$ for $5 \mathrm{~min}$. Then the supernatant was transferred into a new $50 \mathrm{~mL}$ tube and filtered by a $0.22 \mu \mathrm{m}$ microfiltration membrane to ensure that no bacterium stayed in the media. After that, $10 \mathrm{~mL}$ sterile culture medium was collected and diluted in $100 \mathrm{~mL}$ Milli-Q water. Finally, the residual amounts of PFOA after the culturing process were determined according to the same method with Chapter 2.2.

\subsection{Quality assurance and quality control}

To minimize background contamination, the use of polytetrafluoroethylene (PTFE) or other fluoropolymer materials was avoided during collection and extraction of samples. Besides, sediment samples were kept in three layers of sealed polypropylene (PP) plastic bags. Field blanks, transport blanks, procedure blanks and solvent blanks were conducted to monitor potential interferences during sampling, extraction and instrumental analysis. A ninepoint calibration line with native standards was prepared for quantification of individual PFAAs ranging from 0.01 to $100 \mathrm{ng} / \mathrm{mL}$, which was spiked with $5 \mathrm{ng}$ mass-labelled internal standards. Regression coefficients $\left(\mathrm{r}^{2}\right)$ of calibration curves for all target analytes were over 0.99 . The signal-to-noise $(\mathrm{S} / \mathrm{N})$ ratios of ten and three was defined as the limit of quantification (LOQ) and the limit of detection (LOD), respectively. The LODs were in the range of $0.002 \mathrm{ng} / \mathrm{g}$ to $0.010 \mathrm{ng} / \mathrm{g}$, and the LOQs ranged from $0.03 \mathrm{ng} / \mathrm{g}$ to $0.10 \mathrm{ng} / \mathrm{g}$, dry weight (dw). Matrix spiked recoveries (MSR) ranged from $75 \%$ to $117 \%$. During microbial laboratory experiment, each measurement set up 3 groups of parallel processing and the average was used to make results creditable. The detailed QA/QC information was given in Table S2.

\subsection{Statistical and spatial analysis}

Data analysis were performed by EXCEL 2013 (Microsoft China, Beijing) and IBM SPSS Statistics V21 (SPSS Inc. Quarry Bay, HK). Values of concentrations less than LOQs were set to one-half of the LOQs, and those less than LODs were assigned as values of LODs $/ \sqrt{2}$ (Bao et al., 2011).

\section{Results and discussion}

\subsection{Field investigation}

\subsubsection{Occurrences of PFAAs in sediment samples from the Xiaoqing River}

HPLC-MS/MS method was used for the qualitative and quantitative analysis to obtain the concentrations of 12 PFAAs in sediment samples of the Xiaoqing River. As shown in Fig. 1 and Table S3, the 12 PFAAs were detected in all samples of 10 sites. The total concentrations of PFAAs ( $\sum$ PFAAs) were in the range of 8.44-465.60 ng/g dw. PFOA was the major congener with proportions ranging from $45.73 \%$ to $97.98 \%$ and a mean contribution of 94.21\%. For the concentrations of other PFCAs and PFSAs, the total contribution was less than $5.79 \%$. It should be noted that the result was similar to the investigation of other researches (Zhao et al., 2013; Wang et al., 2016). Previous studies showed that the average concentration of $\sum$ PFAAs was $0.21 \mathrm{mg} / \mathrm{L}$ in the water of Xiaoqing River, and PFOA was principal with average and highest concentration of $0.11 \mathrm{mg} / \mathrm{L}$ and $0.97 \mathrm{mg} / \mathrm{L}$ respectively, which made 


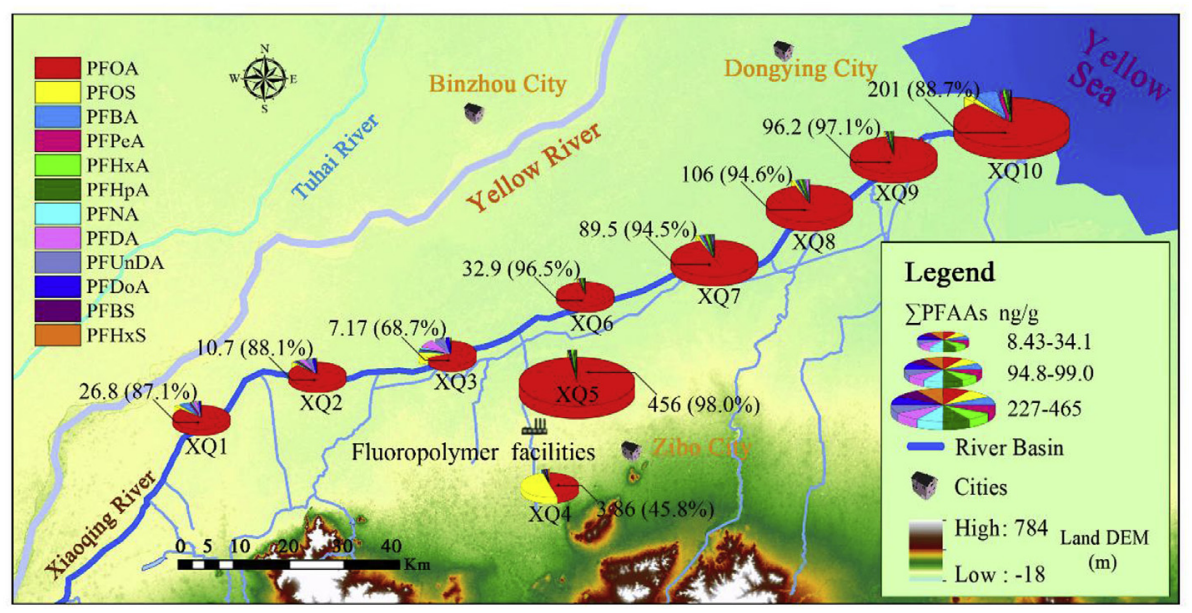

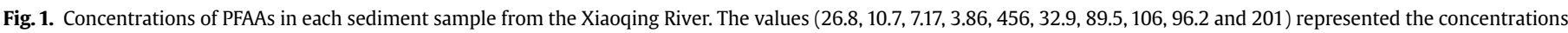

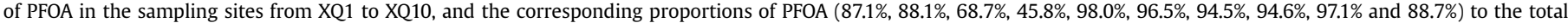
concentrations of PFAAs from XQ1 to XQ10 were shown in the parentheses on the right side of each concentration value separately.

up $91.4 \%$ of $\sum$ PFAAs (Wang et al., 2016). In the same light, Zhao et al. (2013) investigated the concentrations and distributions of PFAAs in surface sediments from Laizhou Bay and its adjacent rivers. The highest concentration $(87.5 \mathrm{ng} / \mathrm{g} \mathrm{dw})$ of $\sum$ PFAAs was detected in Xiaoqing River sediment compared to other rivers around Laizhou Bay. PFOA was found to be the predominant PFAAs, and the sediment from the Xiaoqing River in their study also exhibited the highest concentrations of PFOA (2.6 ng/g to $76.9 \mathrm{ng} /$ $\mathrm{g}$ ). The highly elevated levels of PFOA in the Xiaoqing River could be ascribe to the production of fluorine and other chemical industries along this river (Zhao et al., 2013). Moreover, the sediment samples from the Xiaoqing River revealed a much higher level of PFOA which ranged from 3.86 to $456.20 \mathrm{ng} / \mathrm{g} \mathrm{dw}$ and a mean concentration of $103.14 \mathrm{ng} / \mathrm{g} \mathrm{dw}$. It therefore, indicated that the study area was in the condition of more serious PFOA pollution compared to the counterparts of the South Bohai coastal rivers ranging from 0.01 to $1.05 \mathrm{ng} / \mathrm{g} \mathrm{dw}$, the North Bohai coastal rivers lower than $0.54 \mathrm{ng} / \mathrm{g}$ dw (Wang et al., 2011) and the Pearl River in China (0.09-0.28 ng/g dw) (Bao et al., 2010). The highest concentrations of $\sum$ PFAA (465.60 ng/g dw) and PFOA (456.20 ng/g dw) were found at site XQ5, which was located downstream close to the effluent from one fluorochemical facility that produced PTFE and other fluoropolymers with massive capacity. The concentration of $\sum$ PFAAs was $1.06 \mathrm{mg} / \mathrm{L}$ in water, and PFOA was dominant with the average concentration of $0.97 \mathrm{mg} / \mathrm{L}$, which was $91.3 \%$ of $\sum$ PFAAs (Wang et al., 2016).

\subsubsection{Bacterial composition}

The Illumina high-throughput sequencing was conducted to explore bacterial community diversity and structure. The hierarchically clustered heatmap analysis based on the microbial community profiles at genus level was used to identify the different compositions of microbial community of 10 sample sites. The result of 35 major genera identified in all samples were shown in Fig. 2.

Totally 35,181-114,367 effective sequences were obtained in the sediment samples from Xiaoqing River after removing low quality sequences and chimeras, and then clustered into 2319-4468 OTUs (Table S4). 455 genera were identified in 10 sediment samples. The major 35 genera accounting for $76.9 \%$ of all assigned sequences were summarized in hierarchically clustered heatmap (Fig. 2). The fact that XQ10 was located in the estuary, and the microbial community structure with Lutimonas $(4.81 \%)$ as dominant genera mainly affected by salinity had been discussed in the previous report based on RDA analysis (Sun et al., 2016). Though the other nine sample sites XQ1-XQ9 were all from freshwater with the similar environmental condition (Table S5), Fig. 2 illustrated that XQ5 was distinctly separated from other eight samples (XQ1-XQ4, XQ6-XQ9). In the groups (XQ1-XQ4, XQ6-XQ9), PFOA concentrations of each site were below $100 \mathrm{ng} / \mathrm{g}$, and the main genera were various, such as Thiobacillus (1.5-6.8\%), Dok59 (1.2-4.4\%) and Candidatus Solibacter (0.8-1.3\%) (Table 1). Besides, for every community of these 9 sampling sites, Shannon, Simpson and Chao1 indexes were in the range of 8.53-9.98, 0.003 to 0.0185 and 2608.9 to 3809.8 , respectively (Table S4).

On the contrary, the dominant genera in XQ5 site were minority, nearly representing half of the total sequences (Thiobacillus, $22.9 \%$; Sulfurimonas, 21.9\%). Site XQ5 with the highest concentration of PFOA (456.20 ng/g dw) had the lowest richness and diversity, which were supported by the Chao1 (2508.7), Shannon index (6.76) and Simpson index (0.71). It is speculated that the spatial distribution of the structure of the microbial communities might be correlated with the concentration of PFOA in the sediment of Xiaoqing River.

\subsubsection{Selection of experimental bacteria species}

Thiobacillus was identified as an important genus need to be further study on account of the fact that high level PFOA reduced the diversity of bacterial community, while leading to a notable increase in relative abundance of Thiobacillus. There are 22 species of Thiobacillus cited in the List of Prokaryotic names With Standing in Nomenclature (LPSN). As obligate chemolithoautotrophic bacteria, they all have the capability to utilize $\mathrm{H}_{2} \mathrm{~S}$ as energy source. Within this genus, Thiobacillus thioparus and Thiobacillus denitrificans were selected as target species. On the one hand, it was partly because that previous studies about these bacteria mainly focused on Thiobacillus thioparus, Thiobacillus denitrificans, Thiobacillus thiooxidans and Thiobacillus ferrooxidans (Oprime et al., 2001; Oyarzun et al., 2003; Ma et al., 2006). As a result, the culturing methods of these four species were well-developed, which make it possible to obtain the optimum culture media for bacterial growth. On the other hand, partly because $T$. thioparus and T. denitrificans are neutrophilic bacteria (Chung et al., 2000; Ma et al., 2006), which are adapted to the conditions of the sediment samples from Xiaoqing River with the $\mathrm{pH}$ values ranging from 7.7 to 8.2 (Table S5). While T. thiooxidans and T. ferrooxidans were ruled out for the reason that they are acidophilic bacteria (Aroca et al., 


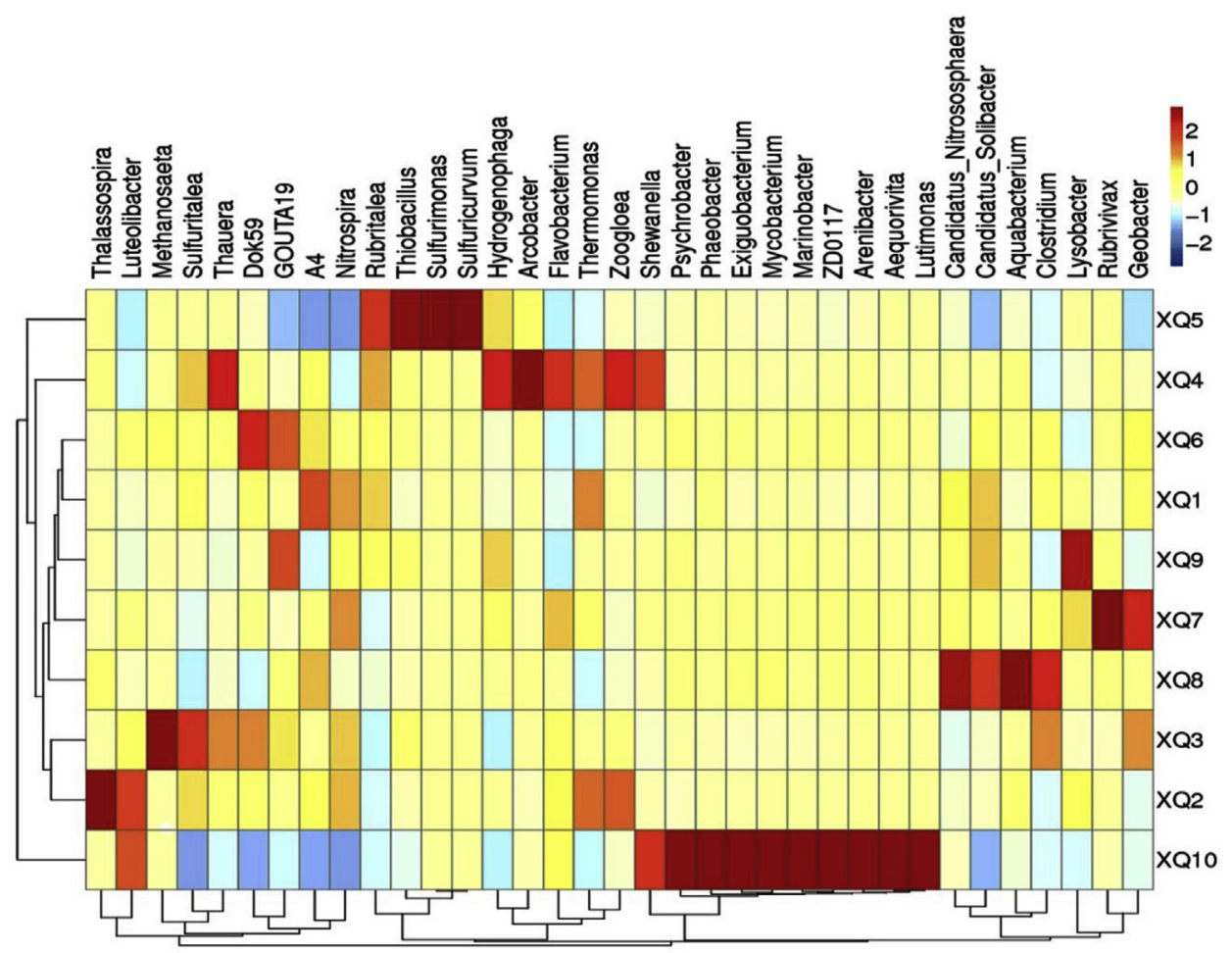

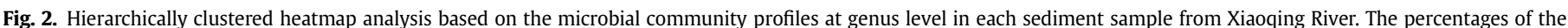

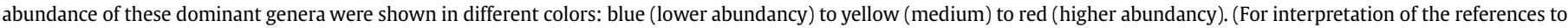
colour in this figure legend, the reader is referred to the web version of this article.)

Table 1

Percentage of the most abundant genus in each sample (\%).

\begin{tabular}{|c|c|c|c|c|c|c|c|c|c|c|}
\hline Items & XQ1 & XQ2 & XQ3 & XQ4 & XQ5 & XQ6 & XQ7 & XQ8 & XQ9 & XQ10 \\
\hline Thiobacillus & 1.53 & 2.22 & 6.84 & 4.52 & 22.91 & 4.40 & 2.27 & 2.41 & 6.49 & 1.07 \\
\hline Sulfurimonas & 0.42 & 0.61 & 0.88 & 1.00 & 21.10 & 0.43 & 0.34 & 0.40 & 0.75 & 0.28 \\
\hline Dok59 & 2.30 & 2.36 & 3.39 & 1.89 & 1.58 & 4.44 & 1.97 & 1.14 & 1.72 & 0.72 \\
\hline Lutimonas & 0.04 & 0.17 & 0.09 & 0.13 & 0.11 & 0.30 & 0.36 & 0.26 & 0.18 & 4.81 \\
\hline Marinobater & 0.16 & 0.24 & 0.16 & 0.16 & 0.14 & 0.46 & 0.51 & 0.38 & 0.42 & 3.16 \\
\hline Aequorivita & 0.04 & 0.08 & 0.07 & 0.03 & 0.05 & 0.14 & 0.17 & 0.14 & 0.07 & 2.13 \\
\hline Rubrivivax & 0.22 & 0.32 & 0.23 & 0.38 & 0.34 & 0.42 & 2.00 & 0.44 & 0.49 & 0.26 \\
\hline Luteolibacter & 0.40 & 1.72 & 0.86 & 0.20 & 0.15 & 0.69 & 0.65 & 0.42 & 0.31 & 1.58 \\
\hline Candidatus Solibacter & 1.04 & 0.83 & 0.87 & 0.77 & 0.31 & 0.85 & 0.79 & 1.40 & 1.00 & 0.33 \\
\hline Sulfuritalea & 0.78 & 0.96 & 1.41 & 1.10 & 0.56 & 0.73 & 0.43 & 0.29 & 0.49 & 0.19 \\
\hline
\end{tabular}

2007; Rastegar et al., 2015), usually utilized in bioleaching studies and hydrometallurgy (Gholami et al., 2011), which are not suitable for neutral environment as our study area.

T. thioparus, as an aerobic bacterium, has been identified capable of oxidizing other organic and inorganic sulphur compounds (Malhautier et al., 2003) and has been widely used in sewage treatment, peat biofilters, composting biofilters and cement biodegradation (Gu et al., 2011; Yousefi et al., 2014). T. denitrificans, as a faculative anaerobe, is well known for its ability to conduct the oxidation of various sulfides and the reduction of iron compounds through denitrification (Beller et al., 2006). It plays an important role in the treatment of drinking water, groundwater and wastewater (Koenig and Liu, 2001; Sierra-Alvarez et al., 2007; Sahinkaya et al., 2011). Therefore, $T$. thioparus and T. denitrificans were selected as receptors to investigate their biosorption behavior towards PFOA by measuring growth curves under the conditions of different PFOA concentrations, as well as the residual rate of PFOA after cultivation process in the liquid media.

\subsection{Indoor experiment}

\subsubsection{Variations in growth curve of T. thioparus and T. denitrificans}

Fig. 3(a) illustrated the growth curves of $T$. thioparus in different PFOA concentrations with the time. The growth curve of CK $(0 \mathrm{ng} / \mathrm{L}$ of PFOA) showed that the postponing stage of $T$. thioparus took approximately $24 \mathrm{~h}$ due to its inadaptability to a new environment. During the logarithmic phase (about $36 \mathrm{~h}$ ), the growth rate of T. thioparus reached its peak in each treatment. After culturing $60 \mathrm{~h}$, the growth of $T$. thioparus slowed down and maintained equilibrium between cell growth and death, due to the environmental deterioration caused by the accumulation of metabolic products and the consumption of nutrients. The growth curves of $T$. thioparus were in accordance with other studies (Gu et al., 2011; Mirzaei et al., 2014).

As Fig. 3(a) showed, the cell growth was positively affected by the presence of PFOA. The growth curves of the 10 treatments were about the same at the postponing stage and then divided. From 0 to 

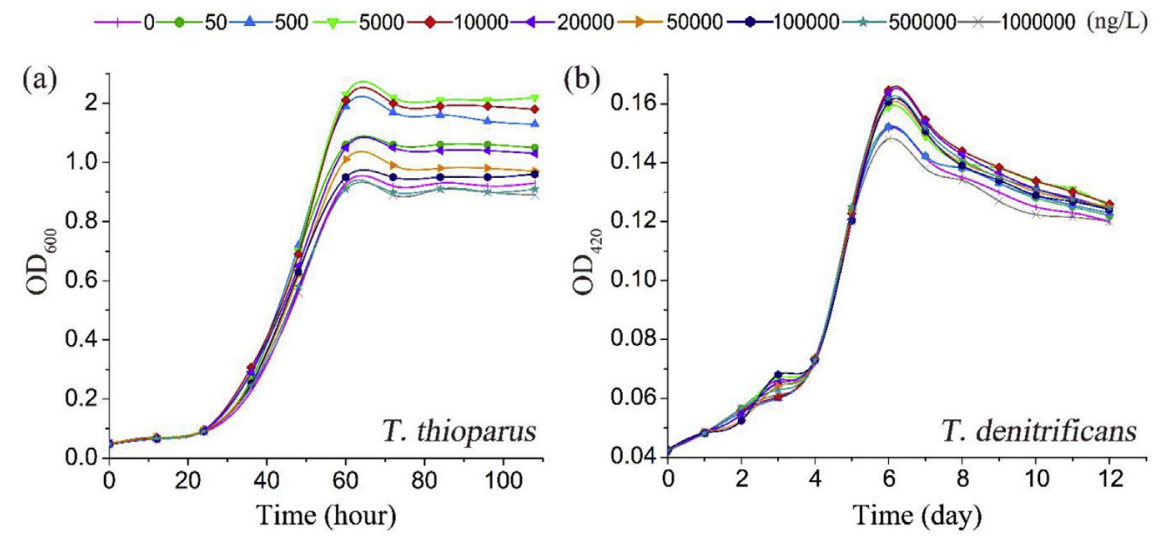

Fig. 3. Variations in growth curves of $T$. thioparus (a) and $T$. denitrificans (b).

$5000 \mathrm{ng} / \mathrm{L}$, the increasing concentrations of PFOA led to a corresponding increase in growth rate during logarithmic phase. The maximum OD value of each treatment got larger accordingly, and the largest value (1.23) was obtained at $5000 \mathrm{ng} / \mathrm{L}$ concentration treatment, which was 1.32 times of CK. However, the higher concentrations of PFOA from 5000 to $100,000 \mathrm{ng} / \mathrm{L}$ resulted in reducing the promotion degree of the growth rate gradually. When the concentration of PFOA exceeded 500,000 ng/L, the growth of T. thioparus was a little inhibited with lower OD values than $\mathrm{CK}$, but the inhibitory effect was not obvious.

Fig. 3(b) exhibited the growth curves of T. denitrificans in 10 treatments with different PFOA concentrations. It showed that T. denitrificans grew slowly and took a relatively long time (4 d) at the postponing stage. During the logarithmic phase (about $2 \mathrm{~d}$ from day 4 to day 6 ), the growth of $T$. denitrificans was active. However, no obvious stable growth period could be found, and the growth of $T$. denitrificans slowed down and gradually entered the decline phase. This was consistent with previous studies (Madigan et al., 2010). The growth curves of the 10 treatments were almost the same at the postponing stage and the early logarithmic phase. About five day after the beginning of cultivation, PFOA (from 5000 to $100,000 \mathrm{ng} / \mathrm{L}$ ) started to stimulate the growth of $T$. denitrificans and the maximum OD (0.165) was obtained at $10,000 \mathrm{ng} / \mathrm{L}$ concentration treatment, which was 1.08 times of CK. No significant promotion or inhibition was observed at other PFOA concentration treatments. In general, PFOA promoted the growth of $T$. denitrificans in a relatively limited range of concentration, and the effect was not obvious. Based on these analysis mentioned above, T. thioparus could survive in high level of PFOA contamination, and was much better-adapted compared to $T$. denitrificans.

PFOA is a long-chain perfluorinated chemical that has been proved to be microbiologically inert and persistent in the environment by some scientists (Stasinakis et al., 2008; Liou et al., 2010). It had been speculated that PFOA might be susceptible to reductive defluorination by microbial communities, and then experiments was designed to examine potential biodegradation of PFOA. However, no changes of molecular configuration of PFOA was observed during experiments, which illustrated that PFOA was not involved in metabolic reactions. In the light of these findings, it could be concluded that PFOA was not a nutrient for T. thioparus in this experiment, even though it played a role in accelerating the growth of $T$. thioparus within a certain range. In previous studies, the concentrations of PFOA in the water bodies of China and other Asian countries were far less than $5000 \mathrm{ng} / \mathrm{L}$, such as Liaoning (2.6-82 ng/L) (Wang et al., 2012), Chongqing (n.d.-35 ng/L) (So et al., 2007), Shanghai (22-260 ng/L) (So et al., 2007), Dalian
Coast (0.17-37.6 ng/L) (Ju et al., 2008), Yodo River basin, Japan $(4.2-2600 \mathrm{ng} / \mathrm{L})$ (Lien et al., 2008), Coast of Korea $(0.24-320 \mathrm{ng} / \mathrm{L})$ (So et al., 2004) and Cooum River, India (0.04-23.1 ng/L) (Yeung et al., 2009). Even in contaminated water bodies close to fluorine industries, the concentrations were still less than $5000 \mathrm{ng} / \mathrm{L}$, such as the Daling River in Liaoning province (n.d.-2280 ng/L) (Zhu et al., 2015) and the Xiaoqing River in Shandong province (1919-4534 ng/L) (Wang et al., 2014). In a nut shell, increasing concentrations of PFOA below $5000 \mathrm{ng} / \mathrm{L}$ would lead to a relatively obvious acceleration in the growth of T. thioparus, which is applicable to most natural water bodies in Asian countries.

\subsubsection{Variations of $\mathrm{pH}$ during the culturing of $T$. thioparus and T. denitrificans}

Fig. 4(a) showed the pH variations in the media of $T$. thioparus. The $\mathrm{pH}$ values of the ten PFOA treatments exhibited no significant difference during the culturing. The $10 \mathrm{pH}$ values rose to about 7.8 after $24 \mathrm{~h}$ and the initial minor rise in $\mathrm{pH}$ might be on account of its inadaptability to a new environment, with the emission of $\mathrm{NH}_{3}$. As the growth process got into the logarithmic phase, the $\mathrm{pH}$ values dropped approximately to 7 on the $60 \mathrm{~h}$ for all the treatments of T. thioparus, because of the increasing concentrations of $\mathrm{H}^{+}$produced by the oxidation of thiosulfate under the action of T. thioparus. Then the $\mathrm{pH}$ reduced slowly and eventually stabilized at 6.9. Fig. 4(b) showed that the $\mathrm{pH}$ variations in the media of T. denitrificans were very little for the ten PFOA treatments as well, and the $\mathrm{pH}$ decreased with the growth and reproduction of $T$. denitrificans. During the logarithmic phase, the growth of T. denitrificans speeded up and the $\mathrm{pH}$ decreased rapidly from 6.8 to 6.4 due to the large number of $\mathrm{H}^{+}$produced by denitrification. Then the $\mathrm{pH}$ changed to flat. The results indicated that the addition of PFOA had no obvious effects on $\mathrm{pH}$ values in the media of both T. thioparus and T. denitrificans, which further illustrated that PFOA didn't participate in the metabolism of bacteria.

\subsubsection{PFOA in the media of T. thioparus and T. denitrificans}

Concentrations of PFOA in the liquid media of T. thioparus and T. denitrificans were summarized in Fig. 5. As the initial culturing concentrations increased from $50 \mathrm{ng} / \mathrm{L}$ to $1,000,000 \mathrm{ng} / \mathrm{L}$, both groups showed increase in residual rate (the final and initial PFOA concentration ratio) substantially. This illustrated that higher treatment concentrations of PFOA resulted in higher residual rates in the liquid media. In T. thioparus group, the final PFOA concentrations accounted for $73.2-78.9 \%$ of initial concentrations with the highest percentage in $1,000,000 \mathrm{ng} / \mathrm{L}$ treatment and the lowest percentage in $50 \mathrm{ng} / \mathrm{L}$ treatment. As for T. denitrificans group, the 

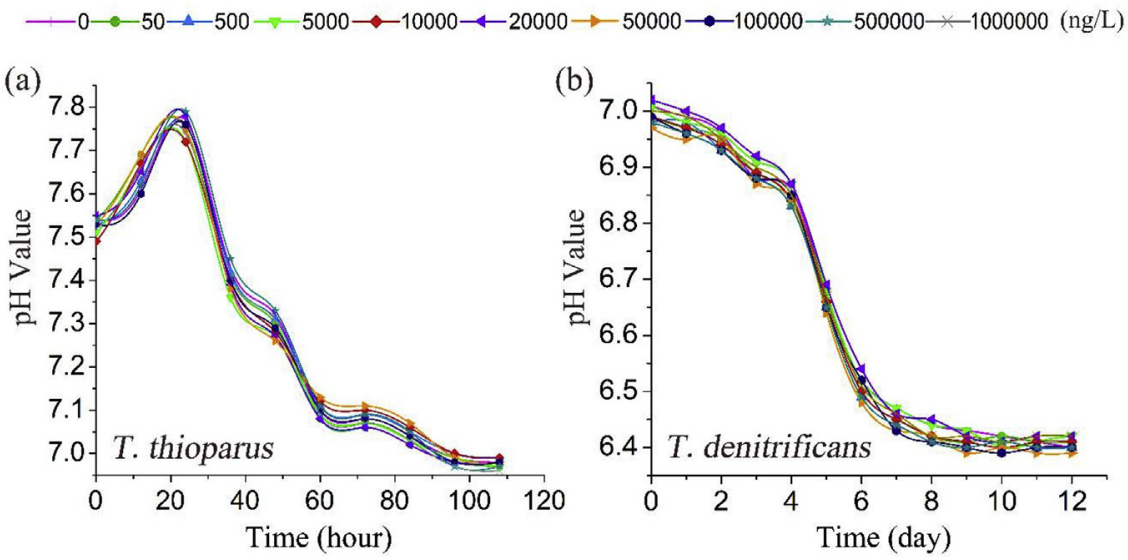

Fig. 4. Variations of $\mathrm{pH}$ in media by culturing T. thioparus (a) and T. denitrificans (b).

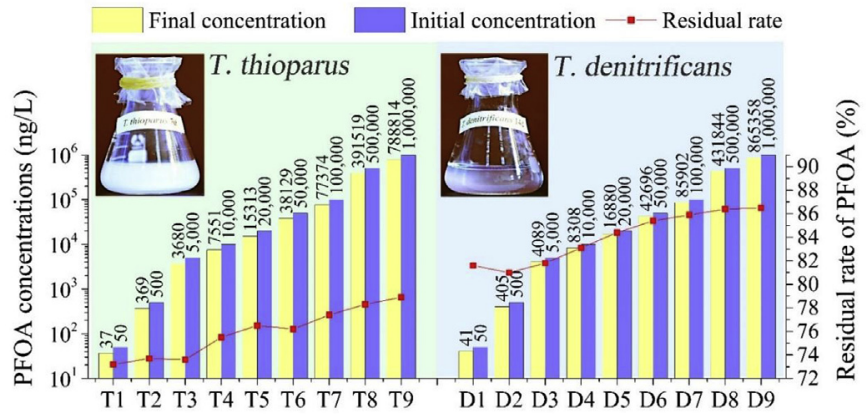

Fig. 5. Initial and final PFOA concentrations in the media of $T$. thioparus and T. denitrificans in different treatments and their residual rates of PFOA. Residual rate was the final and initial PFOA concentration ratio of T. thioparus and T. denitrificans; T1 to T9 and D1 to D9 represented the treatments of different PFOA concentrations (50, $\left.500,5000,10^{4}, 2 \times 10^{4}, 5 \times 10^{4}, 10^{5}, 5 \times 10^{5}, 10^{6} \mathrm{ng} / \mathrm{L}\right)$ of $T$. thioparus and T. denitrificans, respectively.

highest residual rate of PFOA appeared in the treatment of $1,000,000 \mathrm{ng} / \mathrm{L}$ with the percentage of $86.5 \%$, while the lowest rate was $81.0 \%$ in $500 \mathrm{ng} / \mathrm{L}$ treatment. It was noticeable that $T$. thioparus could effectively reduce PFOA content in liquid media, and the removal rates were $21.1 \%-26.8 \%$, which has important ecological significance for the management of water polluted by PFOA. The removal rates of $T$. denitrificans were $13.5 \%-18.4 \%$, which also has the ability to reduce PFOA but much weaker than T. thioparus.

Comparing the two groups, we could see the residual rate of T. thioparus in each treatment was lower than that of $T$. denitrificans. The difference was likely related to bacterial biomass, just as shown in Fig. 3. The OD value of each treatment of T. thioparus was 7.31-9.76 times larger than the counterpart of $T$. denitrificans after the process of bacteria cultivation. The cell wall of bacteria is the first component that comes into contact with pollutants, where the mechanisms responsible for the pollutant uptake will differ (Aksu, 2005). As PFOA didn't participate in metabolism of bacteria according to the above analysis, it was proposed that PFOA could be absorbed by the surface of bacteria, which need further study.

The ten grades of PFOA concentrations $\left(0,50,500,5000,10^{4}\right.$, $2 \times 10^{4}, 5 \times 10^{4}, 10^{5}, 5 \times 10^{5}, 10^{6} \mathrm{ng} / \mathrm{L}$ ) designed in our microbial indoor experiments was in the range of 0 to about the highest concentration in the water of the Xiaoqing River ( $0.97 \mathrm{mg} / \mathrm{L}$ ) (Wang et al., 2016). The greatest value was found in sampling site located right in our X5 site. In addition, PFOA concentrations ranged from 2.6 to $6.6 \times 104 \mathrm{ng} / \mathrm{L}$ in influent from typical municipal and industrial wastewater treatment plants (WWTPs) in China, and these levels were much higher compared to the counterparts of Japan ranging from 14 to $41 \mathrm{ng} / \mathrm{L}$ (Murakami et al., 2009), USA lower than $24 \mathrm{ng} / \mathrm{L}$ (Schultz et al., 2006), Singapore (214.1-638.2 ng/L) (Yu et al., 2009), and Korea in the range of $2.3-615 \mathrm{ng} / \mathrm{L}$ (Guo et al., 2010). The PFOA concentrations in bacterial cultivation of our study would be not only appropriate to the PFOA levels in water of the Xiaoqing River, but also in the influent from WWTPs. As a result, the result of our experiments could illustrate that it was possible to observe the biosorption effects based on the practical levels of PFOA in environment as well as the sewage of WWTPs, which set up a somewhat reasonable scope and foundation for this study.

\section{Conclusions and perspectives}

Systematic research was basically designed on identification of biosorption effects of Thiobacillus towards PFOA by combing results from field and laboratory strategies in present study. In terms of field investigation, PFOA was found as the predominant PFAAs in all sediment samples near fluoropolymer facilities, and the phenomenon that higher concentration of PFOA could increase relative abundance of Thiobacillus was discovered. Given the environmental factors in the study area, Thiobacillus thioparus and Thiobacillus denitrificans were chosen as experimental objects. The results showed that increasing concentrations of PFOA below $5000 \mathrm{ng} / \mathrm{L}$ could lead to a comparatively noticeable increase in growth rate of T. thioparus, but T. denitrificans was not suitable compared with the former. To both T. thioparus and T. denitrificans, the treatments of different PFOA concentrations had no obvious effects on $\mathrm{pH}$, which illustrated that PFOA didn't participate in metabolism. In addition, the same amount of initial inoculation of the two species resulted in different removal rate of PFOA after their growth cycle. The removal rate of PFOA to T. thioparus was $21.1-26.8 \%$, while $13.5-18.4 \%$ to $T$. denitrificans. The results enlightened that $T$. thioparus could grow and thrive in high PFOA concentrations, as well as absorbing PFOA in aquatic environment effectively. Therefore, $T$. thioparus could be used as biosorbent for PFOA abatement and remediation. To our knowledge, the present study provided the first investigation on PFOA biosorption ability of $T$. thioparus in aquatic environment. Not only did our discovery provide bacteria resources and theoretical foundation for biological treatment of PFOA, but also had an important guiding significance in ecological decontamination and pollutant management. It is recommended that more attention should be given to the study of $T$. thioparus with respect to the adsorption mechanism and the influencing factors of removal 
behavior. In the meantime, further research works are needed to improve the biosorption capacity and efficiency of this biological adsorbent and functional bacteria strain.

\section{Acknowledgement}

This study was supported by the National Natural Science Foundation of China under Grant No. 41571478 and the National Water Pollution Control and Treatment Science and Technology Major Project with Grant No. 2015ZX07203-005. We would like to thank the editors and reviewers for their valuable comments and suggestions.

\section{Appendix A. Supplementary data}

Supplementary data related to this article can be found at http:// dx.doi.org/10.1016/j.chemosphere.2016.12.039.

\section{References}

Aksu, Z., 2005. Application of biosorption for the removal of organic pollutants: a review. Process Biochem. 40, 997-1026.

Aroca, G., Urrutia, H., Núñez, D., Oyarzún, P., Arancibia, A., Guerrero, K., 2007. Comparison on the removal of hydrogen sulfide in biotrickling filters inoculated with Thiobacillus thioparus and Acidithiobacillus thiooxidans. Electron. J. Biotechnol. 10, 514-520.

Aytar, P., Gedikli, S., Buruk, Y., Cabuk, A., Burnak, N., 2014. Lead and nickel biosorption with a fungal biomass isolated from metal mine drainage: box-Behnken experimental design. Int. J. Environ. Sci. Technol. 11, 1631-1640.

Bao, J., Liu, W., Liu, L., Jin, Y., Dai, J., Ran, X., Zhang, Z., Tsuda, S., 2011. Perfluorinated compounds in the environment and the blood of residents living near fluorochemical plants in Fuxin, China. Environ. Sci. Technol. 45, 8075-8080.

Bao, J., Liu, W., Liu, L., Jin, Y., Ran, X., Zhang, Z., 2010. Perfluorinated compounds in urban river sediments from Guangzhou and Shanghai of China. Chemosphere $80,123-130$.

Bates, S.T., Berg-Lyons, D., Caporaso, J.G., Walters, W.A., Knight, R., Fierer, N., 2011. Examining the global distribution of dominant archaeal populations in soil, ISME J. 5, 908-917.

Beller, H.R., Chain, P.S.G., Letain, T.E., Chakicherla, A., Larimer, F.W., Richardson, P.M., Coleman, M.A., Wood, A.P., Kelly, D.P., 2006. The genome sequence of the obligately chemolithoautotrophic, facultatively anaerobic bacterium Thiobacillus denitfificans. J. Bacteriol. 188, 1473-1488.

Chung, Y.C., Huang, C.P., Tseng, C.P., Pan, J.R., 2000. Biotreatment of $\mathrm{H}_{2} \mathrm{~S}^{-}$and $\mathrm{NH}_{3}^{-}$containing waste gases by co-immobilized cells biofilter. Chemosphere 41 , 329-336.

Deniz, F., Ersanli, E.T., 2016. Simultaneous bioremoval of two unsafe dyes from aqueous solution using a novel green composite biosorbent. Microchem. J. 128, $312-319$.

Deniz, F., Kepekci, R.A., 2016. Dye biosorption onto pistachio by-product: a green environmental engineering approach. J. Mol. Liq. 219, 194-200.

Dobson, R.S., Burgess, J.E., 2007. Biological treatment of precious metal refinery wastewater: a review. Miner. Eng. 20, 519-532.

Edgar, R.C., 2013. UPARSE: highly accurate OTU sequences from microbial amplicon reads. Nat. Methods 10, 996-998.

Fomina, M., Gadd, G.M., 2014. Biosorption: current perspectives on concept, definition and application. Bioresour. Technol. 160, 3-14.

Gholami, R.M., Borghei, S.M., Mousavi, S.M., 2011. Bacterial leaching of a spent MoCo-Ni refinery catalyst using Acidithiobacillus ferrooxidans and Acidithiobacillus thiooxidans. Hydrometallurgy 106, 26-31.

Giesy, J.P., Kannan, K., 2001. Global distribution of perfluorooctane sulfonate in wildlife. Environ. Sci. Technol. 35, 1339-1342.

Giesy, J.P., Kannan, K., 2002. Perfluorochemical surfactants in the environment. Environ. Sci. Technol. 36, 146A-152A.

Gu, W., Zhang, F., Xu, P., Tang, S., Xie, K., Huang, X., Huang, Q., 2011. Effects of sulphur and Thiobacillus thioparus on cow manure aerobic composting. Bioresour. Technol. 102, 6529-6535.

Guo, R., Sim, W.J., Lee, E.S., Lee, J.H., Oh, J.E., 2010. Evaluation of the fate of perfluoroalkyl compounds in wastewater treatment plants. Water Res. 44 3476-3486.

Hlihor, R.M., Diaconu, M., Leon, F., Curteanu, S., Tavares, T., Gavrilescu, M., 2015. Experimental analysis and mathematical prediction of $\mathrm{Cd}(\mathrm{II})$ removal by biosorption using support vector machines and genetic algorithms. New Biotechnol. 32, 358-368.

Hori, H., Nagaoka, Y., Yamamoto, A., Sano, T., Yamashita, N., Taniyasu, S., Kutsuna, S., Osaka, I., Arakawa, R., 2006. Efficient decomposition of environmentally persistent perfluorooctanesulfonate and related fluorochemicals using zerovalent iron in subcritical water. Environ. Sci. Technol. 40, 1049-1054.

Imandi, S.B., Chinthala, R., Saka, S., Vechalapu, R.R., Nalla, K.K., 2014. Optimization of chromium biosorption in aqueous solution by marine yeast biomass of
Yarrowia lipolytica using Doehlert experimental design. Afr. J. Biotechnol. 13, 1413-1422.

Ju, X., Jin, Y., Sasaki, K., Saito, N., 2008. Perfluorinated surfactants in surface, subsurface water and microlayer from Dalian Coastal waters in China. Environ. Sci. Technol. 42, 3538-3542.

Kissa, E., 2001. Fluorinated Surfactants and Repellents. CRC Press.

Koenig, A., Liu, L.H., 2001. Microbial aspects of autotrophic denitrification of wastewaters. In: Satoh, T.M.H.T. (Ed.), Advances in Water and Wastewater Treatment Technology. Elsevier Science B.V., Amsterdam, pp. 217-226.

Krusic, P.J., Marchione, A.A., Roe, D.C., 2005. Gas-phase NMR studies of the thermolysis of perfluorooctanoic acid. J. Fluor. Chem. 126, 1510-1516.

Kwak, I.S., Won, S.W., Chung, Y.S., Yun, Y.S., 2013. Ruthenium recovery from acetic acid waste water through sorption with bacterial biosorbent fibers. Bioresour. Technol. 128, 30-35.

Lau, C., Anitole, K., Hodes, C., Lai, D., Pfahles-Hutchens, A., Seed, J., 2007. Perfluoroalkyl acids: a review of monitoring and toxicological findings. Toxicol. Sci. 99, 366-394.

Li, M.J., Yu, Z.B., Liu, Q., Sun, L., Huang, W.Y., 2016. Photocatalytic decomposition of perfluorooctanoic acid by noble metallic nanoparticles modified TiO2. Chem. Eng. J. 286, 232-238.

Lien, N.P.H., Fujii, S., Tanaka, S., Nozoe, M., Tanaka, H., 2008. Contamination of perfluorooctane sulfonate (PFOS) and perfluorooctanoate (PFOA) in surface water of the Yodo River basin (Japan). Desalination 226, 338-347.

Liou, J.S.C., Szostek, B., DeRito, C.M., Madsen, E.L., 2010. Investigating the biodegradability of perfluorooctanoic acid. Chemosphere 80, 176-183.

Ma, R., Shih, K., 2010. Perfluorochemicals in wastewater treatment plants and sediments in Hong Kong. Environ. Pollut. 158, 1354-1362.

Ma, Y.L., Yang, B.L., Zhao, J.L., 2006. Removal of $\mathrm{H}_{2} \mathrm{~S}$ by Thiobacillus denitrificans immobilized on different matrices. Bioresour. Technol. 97, 2041-2046.

Magoč, T., Salzberg, S.L., 2011. FLASH: fast length adjustment of short reads to improve genome assemblies. Bioinformatics 27, 2957-2963.

Mak, Y.L., Taniyasu, S., Yeung, L.W., Lu, G., Jin, L., Yang, Y., Lam, P.K., Kannan, K., Yamashita, N., 2009. Perfluorinated compounds in tap water from China and several other countries. Environ. Sci. Technol. 43, 4824-4829.

Malhautier, L., Gracian, C., Roux, J.C., Fanlo, J.L., Le Cloirec, P., 2003. Biological treatment process of air loaded with an ammonia and hydrogen sulfide mixture. Chemosphere 50, 145-153.

Mezaguer, M., el hayet Kamel, N., Lounici, H., Kamel, Z., 2013. Characterization and properties of Pleurotus mutilus fungal biomass as adsorbent of the removal of uranium (VI) from uranium leachate. J. Radioanal. Nucl. Chem. 295, 393-403.

Madigan, M.T., Clark, D.P., Stahl, D., Martinko, J.M., 2010. Brock Biology of Microorganisms, 13th ed. Benjamin Cummings.

Mirzaei, M., Amoabediny, G., Yazdian, F., Sheikhpour, M., Ebrahimi, E., Zadeh, B.E.H. 2014. An immobilized Thiobacillus thioparus biosensing system for monitoring sulfide hydrogen; optimized parameters in a bioreactor. Process Biochem. 49, 380-385.

Murakami, M., Shinohara, H., Takada, H., 2009. Evaluation of wastewater and street runoff as sources of perfluorinated surfactants (PFSs). Chemosphere 74, 487-493.

Naile, J.E., Khim, J.S., Wang, T., Chen, C., Luo, W., Kwon, B.O., Park, J., Koh, C.H. Jones, P.D., Lu, Y., 2010. Perfluorinated compounds in water, sediment, soil and biota from estuarine and coastal areas of Korea. Environ. Pollut. 158, 1237-1244.

Ochoa-Herrera, V., Sierra-Alvarez, R., Somogyi, A., Jacobsen, N.E., Wysocki, V.H., Field, J.A., 2008. Reductive defluorination of perfluorooctane sulfonate. Environ. Sci. Technol. 42, 3260-3264.

Olsen, G.W., Butenhoff, J.L., Zobel, L.R., 2009. Perfluoroalkyl chemicals and human fetal development: an epidemiologic review with clinical and toxicological perspectives. Reprod. Toxicol. 27, 212-230.

Oprime, M., Garcia, O., Cardoso, A.A., 2001. Oxidation of H2S in acid solution by Thiobacillus ferrooxidans and Thiobacillus thiooxidans. Process Biochem. 37 $111-114$.

Oyarzun, P., Arancibia, F., Canales, C., Aroca, G.E., 2003. Biofiltration of high concentration of hydrogen sulphide using Thiobacillus thioparus. Process Biochem. 39, 165-170.

Persson, S., Rotander, A., Karrman, A., van Bavel, B., Magnusson, U., 2013. Perfluoroalkyl acids in subarctic wild male mink (Neovison vison) in relation to age, season and geographical area. Environ. Int. 59, 425-430.

Rastegar, S.O., Mousavi, S.M., Shojaosadati, S.A., Sarraf Mamoory, R., 2015. Bioleaching of $\mathrm{V}, \mathrm{Ni}$, and $\mathrm{Cu}$ from residual produced in oil fired furnaces using Acidithiobacillus ferrooxidans. Hydrometallurgy 157, 50-59.

Rayne, S., Forest, K., 2009. Perfluoroalkyl sulfonic and carboxylic acids: a critica review of physicochemical properties, levels and patterns in waters and wastewaters, and treatment methods. J. Environ. Sci. Health Part A-Toxic/Hazardous Subst. Environ. Eng. 44, 1145-1199.

Sahinkaya, E., Dursun, N., Kilic, A., Demirel, S., Uyanik, S., Cinar, O., 2011. Simultaneous heterotrophic and sulfur-oxidizing autotrophic denitrification process for drinking water treatment: control of sulfate production. Water Res. 45 6661-6667.

Schultz, M.M., Higgins, C.P., Huset, C.A., Luthy, R.G., Barofsky, D.F., Field, J.A., 2006 Fluorochemical mass flows in a municipal wastewater treatment facility. Environ. Sci. Technol. 40, 7350-7357.

Sierra-Alvarez, R., Beristain-Cardoso, R., Salazar, M., Gómez, J., Razo-Flores, E. Field, J.A., 2007. Chemolithotrophic denitrification with elemental sulfur for groundwater treatment. Water Res. 41, 1253-1262. 
So, M.K., Miyake, Y., Yeung, W.Y., Ho, Y.M., Taniyasu, S., Rostkowski, P., Yamashita, N., Zhou, B.S., Shi, X.J., Wang, J.X., Giesy, J.P., Yu, H., Lam, P.K.S., 2007. Perfluorinated compounds in the Pearl River and Yangtze River of China. Chemosphere 68, 2085-2095.

So, M.K., Taniyasu, S., Yamashita, N., Giesy, J.P., Zheng, J., Fang, Z., Im, S.H., Lam, P.K.S. 2004. Perfluorinated compounds in coastal waters of Hong Kong, South China, and Korea. Environ. Sci. Technol. 38, 4056-4063.

Soares, E.V., Soares, H.M., 2012. Bioremediation of industrial effluents containing heavy metals using brewing cells of Saccharomyces cerevisiae as a green technology: a review. Environ. Sci. Pollut. Res. 19, 1066-1083.

Stasinakis, A.S., PetalaS, A.V., Mainais, D., Thomaidis, N.S., 2008. Application of the OECD 301F respirometric test for the biodegradability assessment of various potential endocrine disrupting chemicals. Bioresour. Technol. 99, 3458-3467.

Sun, Y., Wang, T., Peng, X., Wang, P., Lu, Y., 2016. Bacterial community composition in sediment polluted by perfluoroalkyl acids (PFAAs) using Illumina highthroughput sequencing. Environ. Sci. Pollut. Res. 23, 10556-10565.

Vijayaraghavan, K., Yun, Y.S., 2008. Bacterial biosorbents and biosorption. Biotechnol. Adv. 26, 266-291.

Wang, P., Lu, Y., Wang, T., Fu, Y., Zhu, Z., Liu, S., Xie, S., Xiao, Y., Giesy, J.P., 2014 Occurrence and transport of 17 perfluoroalkyl acids in 12 coastal rivers in south Bohai coastal region of China with concentrated fluoropolymer facilities. Environ. Pollut. 190, 115-122.

Wang, P., Lu, Y.L., Wang, T.Y. Meng, J., Li, O.F, Zhu, Z.Y. Sun, Y.J., Wang, R.S., Giesy, J.P., 2016. Shifts in production of perfluoroalkyl acids affect emissions and concentrations in the environment of the Xiaoqing River Basin, China. J. Hazard. Mater. 307, 55-63.

Wang, T., Chen, C., Naile, J.E., Khim, J.S., Giesy, J.P., Lu, Y., 2011. Perfluorinated compounds in water, sediment and soil from Guanting Reservoir, China. Bull.
Environ. Contam. Toxicol. 87, 74-79.

Wang, T., Khim, J.S., Chen, C., Naile, J.E., Lu, Y., Kannan, K., Park, J., Luo, W., Jiao, W. Hu, W., Giesy, J.P., 2012. Perfluorinated compounds in surface waters from Northern China: comparison to level of industrialization. Environ. Int. 42, $37-46$.

Yamamoto, T., Noma, Y., Sakai, S.I., Shibata, Y., 2007. Photodegradation of perfluorooctane sulfonate by UV irradiation in water and alkaline 2-propanol. Environ. Sci. Technol. 41, 5660-5665.

Yeung, L.W.Y. Yamashita, N., Taniyasu, S., Lam, P.K.S., Sinha, R.K., Borole, D.V. Kannan, K., 2009. A survey of perfluorinated compounds in surface water and biota including dolphins from the Ganges River and in other waterbodies in India. Chemosphere 76, 55-62.

Yousefi, A., Allahverdi, A., Hejazi, P., 2014. Accelerated biodegradation of cured cement paste by Thiobacillus species under simulation condition. Int. Biodeterior. Biodegrad. 86, 317-326.

Yu, J., Hu, J., Tanaka, S., Fujii, S., 2009. Perfluorooctane sulfonate (PFOS) and perfluorooctanoic acid (PFOA) in sewage treatment plants. Water Res. 43, 2399-2408.

Zhao, Z., Tang, J., Xie, Z., Chen, Y., Pan, X., Zhong, G., Sturm, R., Zhang, G., Ebinghaus, R., 2013. Perfluoroalkyl acids (PFAAs) in riverine and coastal sediments of Laizhou Bay, North China. Sci. Total Environ. 447, 415-423.

Zhu, Z., Wang, T., Meng, J., Wang, P., Li, Q., Lu, Y., 2015. Perfluoroalkyl substances in the Daling River with concentrated fluorine industries in China: seasonal variation, mass flow, and risk assessment. Environ. Sci. Pollut. Res. 22, 10009-10018

Zhu, Z., Wang, T., Wang, P., Lu, Y., Giesy, J.P., 2014. Perfluoroalkyl and polyfluoroalkyl substances in sediments from South Bohai coastal watersheds, China. Mar. Pollut. Bull. 85, 619-627. 